\title{
Ergenlerde İnternet Bağımlıı̆̆ı ve Psikolojik Belirtilerin Çeşitli Değişkenler Açısından İncelenmesi
}

\section{The Examination of Internet Addiction and Psychological Symptoms Among Adolescents According to Various Variables}

İbrahim Taşa,*

${ }^{a}$ Dr. Öğr. Üyesi, İstanbul Sabahattin Zaim Üniversitesi, Eğitim Fakültesi, Eğitim Bilimleri Bölümü, 34303, İstanbul/Türkiye. ORCID: 0000-0002-5752-2753

\section{MAKALE BILGIISI}

Makale Geçmişi:

Başvuru tarihi: 08 Mayıs 2017

Düzeltme tarihi: 12 Temmuz 2017

Kabul tarihi: 19 Temmuz 2017

\section{Anahtar Kelimeler:}

İnternet Bağımlılığı

Ergenlik

Psikolojik Belirtiler

Anne Baba Tutumu

\section{ARTICLE INFO}

\section{Article history:}

Received 08 May 2017

Received in revised form 12 July 2017

Accepted 19 July 2017

\section{Keywords:}

Internet Addiction

Adolescent

Psychological Symptoms

Parental Attitude

\section{ÖZ}

$\mathrm{Bu}$ araştırmada internet bağımlılığı ile psikolojik belirtiler arasındaki ilişki incelenmiş ve bu kavramlar çeşitli değişkenler açısından değerlendirilmiştir. Araştırma İstanbul'da farklı liselerde öğrenim gören 167'si (\% 39.7) kadın 254'ü (\%60.3) erkek olmak üzere toplam 421 öğrenci üzerinde yürütülmüştür. Araştırmada veri toplama araçları olarak İnternet Bağımlılığı Ölçeği ve Kısa Semptom Envanteri kullanılmıştır. Araştırmada internet bağımlılığı ile psikolojik belirtiler arasında pozitif yönlü ilişki olduğu tespit edilmiştir. İnternet bağımlılığının anne baba tutumları ve internete girme amacına göre anlamlı şekilde farklılaştığı ve internette kalma süresi ile ilişkili olduğu tespit edilmiştir. Psikolojik belirtilerin cinsiyet, anne baba tutumları ve sınıf değişkenine göre anlamlı şekilde farklılaştı̆̆ 1 yaş ve internette kalma süresi ile ilişkili olduğu tespit edilmiştir. Ayrıca psikolojik belirtilerin interneti kullanma amacına göre anlamlı şekilde farklılaşmadığ 1 tespit edilmiştir.

\section{A B S T R A C T}

In this study, the relationship between internet addiction and psychological symptoms is examined. The research is carried out on total 421 high school students studying at different high schools in Istanbul province. 167 (39\%) of them are female and 254 (60,3\%) of them are male. Brief Symptom Inventory and the Internet Addiction Scale were used as data collection tools. In the study, positive correlation between internet addiction and psychological symptoms has been found. It has been identified that internet addiction differs significantly according parental attitudes and the purpose of using the internet. It has been identified that psychological symptoms differ significantly according to gender, parental attitudes and grade level while it is associated with time on the internet and the variable of age.

\section{Giriş}

Her geçen gün daha çok kişinin hayatına giren internet insanlara sunduğu imkânlarla günümüzün vazgeçilmez iletişim araçlarından olmayı başarmıştır. Modern insanın eğlenceden iletişime, günlük işlerden akademik ihtiyaçlara kadar birçok ihtiyacını farklı uygulamalarla karşılamaya başlaması onun tahtını daha da sağlamlaştırmasına yardımcı olmaktadir.

Bilgisayar ağları ile tüm dünyayı birbirine bağlayan internet, sürekli olarak büyüyen, her geçen gün yenilenen, her iş ve ilgi alanındaki kişilere hitap eden bir iletişim ağıdır (Özen vd., 2004). Fiziki dünyanın zaman, mekân ve bedensel sınırlarının ötesinde bir dünya sunan internet (Güzel, 2006) günümüzde ergenler için önemli bir akademik ve eğlence aracı aynı zamanda dünyanın herhangi bir yerindeki birine anlık ve kolay ulaşım sağlayan iletişim aracı haline gelmiştir (Ko vd., 2012). İnternetin kapsayıcılığının giderek artması hemen her yerde giriş imkânının olması, kullanımının kolay olması, sunduğu multimedya kaynaklarının çok ve yüksek kalitede olması (Chou vd., 2005), çok önemli sosyal ve iletişimsel bir araç olması (Yellowlees ve Marks, 2007)

\footnotetext{
* Sorumlu yazar/Corresponding author.

e-posta: ibrahimtas34@gmail.com
} 
internetin her geçen gün daha çok popüler olmasına katkı sağlamaktadır (Karaca, 2007).

Çevrimiçi dünyayı çekici kılan bazı etkenler vardır. İnternet dünyası daha az kısıtlayıcı olması, utangaçlığı yenmeye yardım etmesi ve gizli olması (Griffiths, 2001) gibi bireye sunduğu farklı imkânlar ve durumlarla çekiciliğini sürdürmeye devam etmektedir. Birey gerçek hayatta kuramadığı ilişkileri orada hiçbir risk almadan kurabilmektedir. Bireyler duygu ve düşüncelerini özgürce ifade ettikleri gibi diledikleri zaman kimliklerini gizleyebilecekleri maskeler de kullanabilmektedirler (King, 1996'dan aktaran: Döner, 2011). Birey çevrimiçi dünyada daha önce farkına varamadığı kişiliğinin yeni yüzlerini keşfederek adeta bir yeniden doğuş deneyimi yaşayabilmektedir. İnternet kendini yalnız ve bunalımda hisseden birey için yeni ilişkiler ve arkadaşlıklarla bir can simidi görevi görebilmektedir (Young, 1997). Sanal cemaatler aracılığıyla aidiyet duygusunu yaşayan birey içini döküp rahatlayabilmekte, sosyal baskı ve sorumluluktan uzak yeni bir kimlik edinebilmektedir (Güzel, 2006).

Günümüzde bireyler internette sosyal aktivitelerde bulundukları kadar profesyonel işlerini de yapmaktadırlar. Taşınabilir tablet ve akıllı telefonlarla hemen her yerde çevrimiçi olabilmektedirler. Bireyler nerdeyse çevrimdışı oldukları kadar çevrimiçi hayatlar yaşamaktadırlar. Bu kadar yoğun çevrimiçi olmak beraberinde bazı sorunlar getirebilmektedir (Yao ve Zhong, 2014). Teknolojinin uyumsuz kullanımı psikolojik rahatsızlıklara ya da bozukluklara yol açabilmektedir. $\mathrm{Bu}$ bağlamda teknoloji bağımlılığı konusu son yıllarda yaygın olarak tartışılmaya başlanmış ve literatürde araştırmalar artmaya başlamıştır (Beranuy vd., 2009).

İnternet çoğu kişi için yaşam kalitesi ve iyi oluşu artıran (Arslan, 2017) sağlıklı ve yaratıcı bir araç iken aşırı kullanımı, yarattığı sağlık problemleri, günlük aktiviteleri aksatması ve diğer insanlarla çatışmaya yol açması ile bazıları için problemli bir araç olabilmektedir (Chao ve Hsiao, 2000). İnternet bağımlılığının ne olduğu ile ilgili araştırmacılar arasında standart bir tanım veya tanılamaya yardımcı olacak standart kriterler bulunmamaktadır (Tao vd., 2009). Ancak internet bağımlılığının var olduğu ile ilgili ortak bir kanaat oluşmuştur (Chou vd., 2005). Shapira vd. (2000), problemli internet kullanımını bireyin internet kullanımında kontrolü kaybetmesi ve bu kontrolsüzlüğün günlük yaşamda işlevsizliğe ve bozulmaya yol açması şeklinde tanımlamışlardır. Griffiths (2000), internet bağımlılığını teknolojik bir bağımlılık olarak ele almış ve teknolojik bağımlılıkları da kimyasal olmayan, insan ve makine etkileşimini içeren bir davranışsal bağımlılık olarak tanımlamıştır. Bunun yanında Yao ve Zhong (2014), internet bağımlılığını genel bir davranış kontrol problemi olarak tanımlamışlardır.

İnternet kullanımı son yıllarda özellikle gençler arasında hızla artmakta (Johansson ve Götestam, 2004) çocuk ve ergenlerin yaşam biçimini yeniden şekillendirebilmektedir (Kalkan ve Kaygusuz, 2013). Gelişim dönemi itibariyle ergenlik, duygusal dalgalanmaların yaşandığı (Yörükoğlu, 1986) arkadaşlığın, sosyal çevrenin önemli olduğu (Cüceloğlu, 1994), kimlik bunalımının yaşandığı (Steinberg, 2007) bir dönemdir. Duygusal problemler, sosyalleşme ihtiyacı ve kimlik arayışı gibi etkenler interneti ergenler için çekici (Griffiths, 2001) bir araç haline getirebilmektedir. Bu duygu ve düşüncelerle başlayan aşırı internet kullanımı bireyin sosyal psikolojik dünyasını olumsuz bir şekilde etkileyerek (Odacı ve Çikrıkçi, 2017) problemli bir hal alabilmekte bireyin hayatında sıkıntıya, önemli yaşam alanlarında ise bozulmalara yol açabilmektedir (Shaw ve Black, 2008).

İnternetin problemli kullanımı ile ilgili fikir birliği (Shapira vd., 2000; Shaw ve Black, 2008; Griffiths, 2000; Yao ve Zhong, 2014) olmakla birlikte internet bağımlılığına eşlik eden patolojilerle ilgili çalışma sayısı oldukça sınırlıdır (Davis, 2001). Araştırmacılar internet bağımlılığının diğer bağımlılıklarla oldukça yakın ilişki içinde olduğunu ifade etmişlerdir (Young vd., 1999). İnternet bağımlılarının depresyon, anksiyete ve duygusal problemlere daha yatkın olduğu görülmektedir. Bu bireyler interneti doyurulmamış ihtiyaçlarını doyurmak veya ifade edilmemiş, bastırılmış duygularını açıklamak için kullanmaktadırlar (Young, 1997). Depresyonda olan bazı insanların, internete yönelerek, internette zevkli etkinliklerde bulunarak depresyonlarını tedavi etmeye çalışabileceği görülmektedir (Chou vd., 2005). Depresyonda olan veya yalnızlık yaşayan bireyler uyumsuz bilişlere eğilimli olabilmektedir. Bu kişiler kendilerini sadece internette iyi hissetmektedirler ve onlara göre internetin olmadığı bir dünya korkunç bir dünyadır. Bu yüzden depresif ve yalnız insanlar internet bağımlılı̆̆ına karşı daha kırılgan olabilmektedirler (Yao ve Zhong, 2014). Yukarıda da ifade edildiği gibi psikolojik belirtiler ile internet bağımlılığı arasında net bir ilişki göze çarpmaktadır.

Alan yazın incelendiğinde ergenlerde internet bağımlılığı ile ilgili sınırlı sayıda çalışma göze çarpmaktadır. Ayas (2012) tarafından ergenlerle yapılan çalışmada internet bağımlılığı ile bilgisayar oyun bağımlılığı arasında ve internet ve bilgisayar oyun bağımlılığı ile utangaçlık arasında pozitif ilişki bulunmuştur. Alan yazında internet bağımlılığı ile psikolojik belirtiler arasındaki ilişkiyi gösteren çalışmaların artmaya başladığı görülmektedir. Çalışmalar internet bağımlılığının uyku, yemek yeme problemleri, fiziksel sorunlar, okul ve iş hayatının bozulması gibi problemlerle ilişkili olduğunu göstermektedir (Cao ve $\mathrm{Su}, 2006$ ). Bireylerin yaşadığ 1 psikolojik sorun ve problemlerle internet bağımlılığ bağımlılığının genel psikolojik belirtiler (Batıgün ve Kılıç, 2011), depresyon (Ayas ve Horzum, 2013b; Çetinkaya, 2013; Dalbudak ve Evren, 2014; Kim vd., 2006; Ko vd., 2009; Ko vd., 2012; Shapira vd., 2000; Young ve Rogers, 1998), anksiyete (Bernardi ve Pallanti , 2009; Dalbudak ve Evren, 2014; Jie vd., 2014), sosyal fobi, düşmanlık, madde kullanım bozukluğu ve dikkat eksikliği hiperaktivite bozukluğu (Ko vd., 2009; Ko vd., 2012), dürtü kontrol bozukluğu ve obsesif kompülsif bozukluk (Eroğlu, 2016; Dalbudak vd., 2013; Shapira vd., 2000), kişilerarası duyarlılık (Rahmani ve Lavasani, 2011), fobiler (Bernardi ve Pallanti , 2009; Shapira vd., 2000), psikotizm (Dalbudak ve Evren, 2014; Dalbudak vd., 2013) ve yalnızlı (Ümmet ve Ekşi, 2016; Ayas ve Horzum, 2013b) ile ilişkili olduğunu gösteren çok sayıda çalışmaya rastlanmaktadır. İnternet bağımlılığının cinsiyet ile olan ilişkisine bakıldığında erkeklerin daha çok bağımlı olduğunu gösteren çalışmalar (Monacis vd., 2017; Dalbudak vd., 2013; Ko vd., 2009) olduğu gibi cinsiyet değişkeni açısından anlamlı bir farklılık görmeyen çalışmaların da (Taylan ve Işık, 2015; Kim vd., 2006) olduğu görülmektedir. 
Alan yazın incelendiğinde internet bağımlılı̆̆ı ile psikolojik belirtiler arasında bir ilişki olduğu görülmektedir. Bu nedenle yapılacak çalışmalarda bu ilişkinin ortaya çıkarılması ve internet bağımlılığı ile psikolojik belirtilerin diğer değişkenlerle ilişkisinin belirlenmesi önem arz etmektedir. Bu doğrultuda bu çalışmada internet bağımlılığı ile psikolojik belirtiler arasındaki ilişki incelenmiş ve bu kavramlar çeşitli değişkenler açısından el alınmıştır. Bu amaç doğrultusunda araştırmada aşağıdaki soruların cevapları araştırılmıştır:

(i) Ergenlerde internet bağımlılı̆̆ı ile psikolojik belirtiler arasında bir ilișki var mıdır?

(ii) Cinsiyet değişkenine göre ergenlerde internet bağımlılığı ve psikolojik belirtiler farklılaşmakta midir?

(iii) Anne-baba tutumuna göre ergenlerde internet bağımlılı̆̆ı ve psikolojik belirtiler farklılaşmakta midir?

(iv) İnternete bağlanma amacına göre ergenlerde internet bağımlılı̆̆ ve psikolojik belirtiler farklılaşmakta midir?

(v) Sınıf değişkenine göre ergenlerde internet bağımlılığı ve psikoloji belirtiler farklılaşmakta mıdır?

(vi) İnternette kalma süresi ile internet bağımlılığı ve psikolojik belirtiler arasında bir ilişki var mıdır?

(vii) Yaş değişkeni ile internet bağımlılığı ve psikolojik belirtiler arasında bir ilişki var mıdır?

\section{Yöntem}

\subsection{Araştırma Modeli}

Araştırmada genel tarama modellerinden ilişkisel tarama modeli kullanılmıştır. İlişkisel tarama modelleri iki ve daha fazla sayıdaki değişken arasındaki değişimi bulmayı amaçlayan çalışmalardır (Karasar, 2004).

\subsection{Araştırma Grubu}

Çalışma grubunu 2014-2015 eğitim öğretim y1lında İstanbul'da liselerde öğrenim gören 167 'si (\% 39.7) kadın, 254'ü (\%60.3) erkek 421 öğrenci oluşturmaktadır. Çalışmaya katılan öğrenciler 14-19 yaşları arasında olup ve yaş ortalamaları 15.8 'dir. Öğrencilerin 94'ü (\% 22.3) 9. sinıfa, 146's1 (\%34.7) 10. sinıfa, 150'si (\%35.6) 11. sinıfa ve 31 'i (\%7.4) 12. sinifa devam etmektedir.

\subsection{Veri Toplama Araçları}

\subsubsection{Kişisel Bilgi Formu}

Araştırmaya katılan öğrencilerin sosyo-demografik bilgileri araştırmacı tarafindan hazırlanan kişisel bilgi formu ile alınmıştır.

\subsubsection{Internet Kullanım Bağımlılı̆̆ Ölçeği}

Öğrencilerin internet bağımlılığı düzeyleri Ayas, Çakır ve Horzum (2011) tarafindan geliştirilen "Ergenler İçin Bilgisayar Bağımlılığı Ölçeği” kullanılarak ölçülmüştür. Ölçek 54 madde iki faktörden oluşmaktadır. Birinci faktör 28 maddeden oluşmaktadır. Maddelerin faktör yük değerleri 0.512 ile 0.795 arasında değişmektedir. Ölçeğin toplam varyansının \% 29.49'unu açıklayan bu faktör “internet kullanım bağımlılığı" olarak adlandırılmıștır. İkinci faktör ise, toplam 26 maddeden oluşmaktadır. Bu maddelerin ikinci faktördeki yük değerleri 0.424 ile 0.788 arasında değişmektedir. Ölçeğin toplam varyansının \%19.13'ünü açıklayan bu faktör "bilgisayar oyun bağımlılığı" olarak isimlendirilmiştir. Ölçeğin puanlanmasında 5'li Likert tipi dereceleme kullanılmıştır. Dereceleme "Her zaman", "Çoğu Zaman", "Sıklıkla", "Ara Sıra" ve "Nadiren" ş̧eklinde oluşturulmuştur. Ölçekten alınabilecek en düşük puan 28 puandır. Toplamda alınabilecek en yüksek puan ise 140 puandır. Ölçeğin güvenirliği için Cronbach Alfa iç tutarlılık katsayısı hesaplanmıştır. İç tutarlılık katsayısı internet bağımlılığı için 0.96 ve bilgisayar oyun bağımlılığı için 0.95 olarak bulunmuştur. Ölçeğin toplam iç tutarlılık katsayısı 0.95 olarak bulunmuştur. Bu çalışma kapsamında İnternet Kullanım Bağımlılığı Ölçeğinin Cronbach Alfa katsayısı 0.92 olarak bulunmuştur.

\subsubsection{Klsa Semptom Envanteri}

Derogatis (1992) tarafından geliştirilen Kısa Semptom Envanteri çeşitli tıbbi durumlarda psikiyatrik sorunları yakalamak amacıyla hazırlanmış, 90 maddelik bir ölçek olan SCL-90 -R'nin kısa formudur. 53 madde ve 9 alt ölçek, ek maddeler ve 3 global indeksten oluşan ölçek Şahin ve Durak (1994) tarafından Türkçeye uyarlanmıştır (Akt. Savaşır ve Şahin, 1997). Ölçek 0-4 arası puanlanan likert tipi bir ölçektir. Dereceleme "Hiç yok", "Biraz var", "Orta derecede var", "Epey var" ve Çok fazla var” şeklindedir. Puan aralığı 0-212 arasındadır. Ölçeğin alt boyutları; somatizasyon, obsesif kompülsif bozukluk, kişilerarası duyarlılık/olumsuz benlik, depresyon, anksiyete, hostilite, fobik anksiyete, paranoid düşünce ve psikotizm şeklindedir. Global indeksler ise sırasıyla Rahatsızlık Ciddiyeti İndeksi, Belirti Toplam İndeksi ve Semptom Rahatsızlık İndeksinden oluşmaktadır. Ölçekten alınan toplam puanların yüksekliği bireyin ruhsal belirtilerinin arttığını gösterir. Ölçeğin güvenirliği yapılan çalışmadan elde edilen Cronbach Alfa iç tutarlılık katsayıları ile incelenmiş ve iç tutarlılık katsayıları 0.96 ve 0.95 olarak bulunmuştur. Alt ölçeklerin iç tutarlılık katsayıları 0.55 ve 0.86 şeklindedir. Ölçeğin geçerliği için ölçüt bağıntı geçerlik ve yap1 geçerliğine bakılmıştır. Ölçüt bağıntı geçerlikte ölçeğin Sosyal Karşılaştırma Ölçeği ile -0.14 ve -0.34 arasında, Boyun Eğicilik Ölçeği ile 0.16 ve 0.42 arasında Uçla Yalnızlık Ölçeği ile 0.13 ve 0.36, Offer Yalnızlık Ölçeği ile 0.34 ve -0.57 arasında Beck Depresyon Ölçeği ile 0.34 ve 0.70 arasında değişen ilişkiler gösterdiği tespit edilmiştir. Ölçeğin yapı geçerliğinde Strese Yatkınlık Ölçeğinden alınan puanlar dikkate alınmış ve ölçeğin toplam puanı üzerinden yapılan analiz sonucunda ölçeğin strese yatkın ve strese yatkın olmayan iki uç grubu da anlamlı düzeyde ayırt ettiği görülmüştür (Şavaşır ve Şahin, 1997). Ölçeğin ergenler için uyarlama çalışması Şahin, Durak Batıgün ve Uğurtaş (2002) tarafindan yapılmıştır. Üç ayrı çalışmada ölçeğin toplam puanından elde edilen Cronbach Alfa iç tutarlılık katsayıları 0.96 ve 0.95 , alt ölçekler için elde edilen katsayılar ise 0.55 ve 0.86 arasında değişmektedir. Ergenlerle yapılan başka bir çalışmada da (Yıldırım, Atlı ve Çitil, 2014) iç tutarlılık kat sayısı ölçeğin toplam puanı için 0.95 olarak hesaplanmıştır. Alt ölçeklerin katsayıları 0.57 ile 0.80 arasında değiş̧mektedir. Bu çalışma kapsamında ölçeğin toplam puan Cronbach Alfa katsayısı 0.96 olarak bulunmuştur. 


\subsection{Verilerin Toplanması ve Analizi}

Araştırmaya katılan öğrencilere ölçekler elden dağıtılarak uygulanmıştır. Araştırmanın analizleri SPSS 22 programıyla gerçekleştirilmiştir. Veriler normal dağılıma sahip olmadığından (Kolmogorov-Smirnov $=.000 ; \mathrm{p}<\quad .05$ ) analizlerde parametrik olmayan testler uygulanmıştır.

\section{Bulgular}

Araştırmada öğrencilerin demografik bilgileri şu şekildedir. Çalışmaya katılan öğrenciler 14-19 yaşları arasında olup ve yaş ortalamaları 15.8 'dir. Öğrencilerin günlük internette kalma sürelerinin 0-20 saat arasında değiştiği görülmektedir. Öğrencilerin internette kaldıkları süreye bakıldığında öğrencilerin 79'u (\%18.8) günde 1 saat, 118'i (\%28) günde
2 saat, 84’ü (\%20) günde 3 saat, 36'sı (\%8.6) günde 4 saat, 29 'u (\%6.9) günde 5 saat, 12 'si (\%2.9) günde 6 saat, 11'i (\%2.6) günde 7 saat, 4’ü (\%1) günde 8 saat, 8'i (\%1.9) günde 10 saat ve 25 'i (\%5.9) günde 12 saat internet kullandığını ifade etmiştir. Diğer kullanım oranlarının yüzdelik dilimleri yüzde 1 'in altındadır. İnterneti günde $9,11,13,14,15$ ve 16 saat kullandığını ifade edenlerin toplam sayısı 12 (\%3.1) kişidir. Öğrencilerin interneti kullanma amaçlarına bakıldığında katılımcıların 122'si (\%29) sohbet amaçlı, 113 'ü (\%26.8) eğlence amaçlı, 75'i (\%17.8) araştırma amaçlı, 63'ü (\%15) interneti oyun amaçl1, 28'i (\%6.7) diğer amaçlarla ve 20 'si (\%4.8) haber takip etme amaçlı interneti kullandığını ifade etmiştir. Anne baba tutumları açısından öğrenciler değerlendirildiğinde, katılımcıların 201'i (\%47.7) koruyucu, 129'u (\%30.6) demokratik, 61'i (\%14.5) otoriter ve 30'u (\%7.1) anne babasını ilgisiz olarak değerlendirmiştir

Tablo 1. Değişkenlere Ait Betimsel İstatistikler

\begin{tabular}{|c|c|c|c|c|c|}
\hline Değişken & $n$ & $\bar{X}$ & Ss & $\mathrm{Sh}_{\overline{\mathrm{x}}}$ & $\alpha$ \\
\hline İnternet Bağımlılığ & 421 & 53.35 & 18.06 & .88 & .92 \\
\hline Psikolojik Belirtiler & 421 & 50.90 & 39.32 & 1.91 & .96 \\
\hline Somatizasyon & 421 & 5.31 & 5.70 & .27 & .82 \\
\hline $\mathrm{OKB}$ & 421 & 7.11 & 5.22 & .25 & .76 \\
\hline Kişilerarası Duyarlılık & 421 & 4.28 & 3.91 & .19 & .74 \\
\hline Depresyon & 421 & 6.23 & 5.95 & .29 & .85 \\
\hline Anksiyete & 421 & 4.95 & 5.06 & .24 & .81 \\
\hline Hostilite & 421 & 6.23 & 5.01 & .24 & .79 \\
\hline Fobik Anksiyete & 421 & 3.14 & 3.80 & .18 & .69 \\
\hline Paranoid Düşünce & 421 & 5.51 & 4.36 & .21 & .71 \\
\hline Psikotizm & 421 & 3.98 & 4.02 & .19 & .69 \\
\hline
\end{tabular}

Tablo 2. İnternet Bağımlılığı ile Psikolojik Belirtiler Arasındaki İlişki

\begin{tabular}{lcccccccccc}
\hline Değişkenler & 1 & 2 & 3 & 4 & 5 & 6 & 7 & 8 & 9 & 10 \\
\hline 1. Internet Băg & 1 & & & & & & & & & \\
2. Psikolojik Belirti Top & $.372^{* *}$ & 1 & & & & & & & \\
3. Soma & $.266^{* *}$ & $.791^{* *}$ & 1 & & & & & & \\
4. OKB & $.345^{* *}$ & $.840^{* *}$ & $.624^{* *}$ & 1 & & & & & \\
5. Kişilerara Duy & $.264^{* *}$ & $.805^{* *}$ & $.585^{* *}$ & $.646^{* *}$ & 1 & & & & \\
6. Depresyn & $.329^{* *}$ & $.876^{* *}$ & $.631^{* *}$ & $.714^{* *}$ & $.697^{* *}$ & 1 & & & & \\
7. Anksiyete & $.333^{* *}$ & $.873^{* *}$ & $.705^{* *}$ & $.703^{* *}$ & $.683^{* *}$ & $.728^{* *}$ & 1 & & & \\
8. Hostilite & $.306^{* *}$ & $.793^{* *}$ & $.596^{* *}$ & $.600^{* *}$ & $.575^{* *}$ & $.623^{* *}$ & $.734^{* *}$ & 1 & & \\
9. Fobik Anksiyete & $.303^{* *}$ & $.732^{* *}$ & $.593^{* *}$ & $.613^{* *}$ & $.570^{* *}$ & $.583^{* *}$ & $.618^{* *}$ & $.513^{* *}$ & 1 \\
10. Paranoid Düşünce & $.298^{* *}$ & $.832^{* *}$ & $.585^{* *}$ & $.658^{* *}$ & $.700^{* *}$ & $.716^{* *}$ & $.681^{* *}$ & $.602^{* *}$ & $.570^{* *}$ & 1 \\
11. Psikotz & $.371^{* *}$ & $.832^{* *}$ & $.619^{* *}$ & $.654^{* *}$ & $.633^{* *}$ & $.758^{* *}$ & $.685^{* *}$ & $.632^{* *}$ & $.607^{* *}$ & $.702^{* *}$ \\
\hline
\end{tabular}
$* * \mathrm{p}<.01$

Tablo 3. İnternet Bağımlılığı ile Psikolojik Belirtiler Toplam Puanının Cinsiyet Değişkenine Göre U Testi Sonuçları

\begin{tabular}{|c|c|c|c|c|c|c|}
\hline & Grup & $\mathrm{n}$ & Sira ort & Sira top & $\mathrm{U}$ & $\mathrm{p}$ \\
\hline \multirow{2}{*}{ İnternet Bağımlılığ1 } & Kadın & 167 & 211.72 & 35357.50 & 21088.500 & .921 \\
\hline & Erkek & 254 & 210.53 & 53473.50 & & \\
\hline \multirow{2}{*}{ Psikolojik Belirti } & Kadın & 167 & 259.64 & 43359.50 & 13086.500 & .000 \\
\hline & Erkek & 254 & 179.02 & 45471.50 & & \\
\hline
\end{tabular}

$* * \mathrm{p}<.01$

Tablo 4. İnternet Bağımlılığı ve Psikolojik Belirtiler Toplam Puanının Anne Baba Tutumlarına Göre Kruskal Wallis H Testi Sonuçları

\begin{tabular}{|c|c|c|c|c|c|c|}
\hline & Anne Baba Tutumları & $\mathrm{n}$ & S1ra Ort & $\mathrm{Sd}$ & $x^{2}$ & $\mathrm{P}$ \\
\hline \multirow{4}{*}{ İnternet Bağımlılığ } & İlgisiz & 30 & 229.78 & 3 & 9.284 & .026 \\
\hline & Demokratik & 129 & 191.23 & & & \\
\hline & Otoriter & 61 & 246.36 & & & \\
\hline & Koruyucu & 201 & 210.15 & & & \\
\hline \multirow{4}{*}{ Psikolojik belirtiler } & İlgisiz & 30 & 293.55 & 3 & 22.301 & .000 \\
\hline & Demokratik & 129 & 186.45 & & & \\
\hline & Otoriter & 61 & 237.72 & & & \\
\hline & Koruyucu & 201 & 206.33 & & & \\
\hline
\end{tabular}


Tablo 5. İnternet Bağımlılı̆̆ı ve Psikolojik Belirtilerin İnternete Bağlanma Amacına Göre Kruskal Wallis H Testi Sonuçları

\begin{tabular}{|c|c|c|c|c|c|c|}
\hline & İnternete Bağlanma Amacı & $\mathrm{N}$ & Sira ort & $\mathrm{Sd}$ & $x^{2}$ & $\mathrm{P}$ \\
\hline \multirow{6}{*}{ İnternet Bağımlılığ1 } & Sohbet & 122 & 231.61 & 5 & 47.390 & .000 \\
\hline & Eğlence & 113 & 228.17 & & & \\
\hline & Araştırma & 75 & 130.85 & & & \\
\hline & Oyun & 63 & 252.77 & & & \\
\hline & Diğer & 28 & 186.09 & & & \\
\hline & Haber & 20 & 192.15 & & & \\
\hline \multirow{6}{*}{ Psikolojik Belirtiler } & Sohbet & 122 & 216.26 & 5 & 7.248 & .203 \\
\hline & Eğlence & 113 & 209.45 & & & \\
\hline & Araştırma & 75 & 202.69 & & & \\
\hline & Oyun & 63 & 190.09 & & & \\
\hline & Diğer & 28 & 261.25 & & & \\
\hline & Haber & 20 & 214.38 & & & \\
\hline
\end{tabular}

Tablo 6. İnternet Bağımlılığı ve Psikolojik Belirtilerin Sınıf Değişkenine Göre Kruskal Wallis H Testi Sonuçları

\begin{tabular}{|c|c|c|c|c|c|c|}
\hline & Sinif & $\mathrm{n}$ & Sira Ort & $\mathrm{Sd}$ & $x^{2}$ & $\mathrm{P}$ \\
\hline \multirow{4}{*}{ İnternet Bağımlılığ1 } & 9 & 94 & 204.32 & 3 & 2.347 & .504 \\
\hline & 10 & 146 & 206.99 & & & \\
\hline & 11 & 150 & 212.91 & & & \\
\hline & 12 & 31 & 240.87 & & & \\
\hline \multirow{4}{*}{ Psikolojik Belirtiler } & 9 & 94 & 188.24 & 3 & 16.921 & .001 \\
\hline & 10 & 146 & 192.98 & & & \\
\hline & 11 & 150 & 243.08 & & & \\
\hline & 12 & 31 & 209.68 & & & \\
\hline
\end{tabular}

$* * \mathrm{p}<.05$

Tablo 1'de araştırmada kullanılan değişkenlere ilişkin betimsel istatistikler yer almaktadır. Tablo 1'de internet bağımlılığı ile psikolojik belirtiler toplam puan ile psikolojik belirti alt boyutlarının aritmetik ortalaması standart sapması ve standart hata değerleri ve Cronbach Alfa Değerleri verilmiştir. Buna göre internet bağımlılığının aritmetik ortalamas1 $(\bar{X}) 53.35$ ve standart sapması (ss) 18.06 şeklindedir. Psikolojik belirtilerin aritmetik ortalaması $(\bar{X}$ ) 50.90 ve standart sapmaları (ss) 39.32 şeklindedir. Cronbach Alfa Değerleri $(\alpha)$ internet bağımlılı̆̆ 0.92 ve psikolojik belirtiler toplam puan için .96, somatizasyon için .82, OKB için 0.76, Kişilerarası Duyarlılık için 0.74, Depresyon için 0.85, Anksiyete için 0.81, Hostilite için 0.79, Fobik Anksiyete için 0.69, Paranoid düşünce için 0.71 ve Psikotizm için 0.69 olarak bulunmuştur.

\subsection{Araştırmanın Birinci Sorusuna İlişkin Bulgular}

$\mathrm{Bu}$ kısımda araştırmanın birinci sorusu doğrultusunda ergenlerde internet bağımlılığı ile psikolojik belirtiler arasındaki ilişkiyi belirlemek için Spearman Korelasyon Analizi yapılmış ve sonuçlar Tablo 2'de verilmiştir.

Tablo 2 incelendiğinde ergenlerin internet bağımlılık düzeyleri ile psikolojik belirti düzeyleri arasında orta düzey pozitif yönlü anlamlı bir ilişki olduğu görülmektedir $\left(r_{s}=.37\right.$, $\mathrm{p}<.01$ ). İnternet bağımlılığ 1 ile psikolojik belirti alt boyutları arasındaki ilişkiye bakıldığında internet bağımlılığı ile Somatizasyon $\left(\mathrm{r}_{\mathrm{s}}=.27, \mathrm{p}<.01\right)$ ve Kişilerarası Duyarlılık $\left(\mathrm{r}_{\mathrm{s}}=.26, \mathrm{p}<.01\right)$ arasında düşük düzeyde pozitif yönlü ilişki, internet bağımlılığı ile Obsesif Kompülsif Bozukluk ( $\mathrm{r}_{\mathrm{s}}=.35$, $\mathrm{p}<.01)$, Depresyon $\left(\mathrm{r}_{\mathrm{s}}=.33, \mathrm{p}<.01\right)$, Anksiyete $\left(\mathrm{r}_{\mathrm{s}}=.33\right.$, $\mathrm{p}<.01)$, Hostilite (Düşmanlık) ( $\left.\mathrm{r}_{\mathrm{s}}=.31, \mathrm{p}<.01\right)$, Fobik Anksiyete $\left(\mathrm{r}_{\mathrm{s}}=.30, \mathrm{p}<.01\right)$, Paranoid Düşünce $\left(\mathrm{r}_{\mathrm{s}}=.30, \mathrm{p}<.01\right)$ ve Psikotizm $\left(\mathrm{r}_{\mathrm{s}}=.371, \mathrm{p}<.01\right)$ arasında ise orta düzey pozitif yönlü ilişki olduğu tespit edilmiştir. Bu bulguya göre internet bağımlılığı ile psikolojik belirtiler toplam puanı ve psikolojik belirtilerin tüm alt boyutları arasında anlamlı bir ilişki bulunmaktadır.

\subsection{Araştırmanın İkinci Sorusuna İliş̧kin Bulgular}

$\mathrm{Bu}$ kısımda araştırmanın ikinci sorusu doğrultusunda ergenlerde internet bağımlılığı ile psikolojik belirtilerin cinsiyete göre anlamlı şekilde farklılaşıp farklılaşmadığını belirlemek için Mann-Whitney U testi yapılmış ve sonuçlar Tablo 3'te verilmiştir. Tablo 3 incelendiğinde internet bağımlılığının cinsiyete göre anlamlı şekilde farklılaşmadığı (U=21088, p>.05) görülmüştür. Psikolojik belirtiler toplam puanının $(\mathrm{U}=13086, \mathrm{p}<.05)$ cinsiyete göre anlamlı düzeyde farklılaştığı görülmektedir. Ayrıca psikolojik belirtiler alt boyutlarından, Somatizasyonun $(\mathrm{U}=14349, \mathrm{p}<.05)$, OKB'nin $(\mathrm{U}=13827, \quad \mathrm{p}<.05), \quad$ Kişilerarası duyarlılı̆̆ın $(\mathrm{U}=13388, \mathrm{p}<.05), \quad$ Depresyonun $(\mathrm{U}=13128, \mathrm{p}<.05)$, Anksiyetenin ( $U=13133, \mathrm{p}<.05)$, Hostilitenin ( $U=16069$, $\mathrm{p}<.05)$, Fobik Anksiyetenin (U=16076, $\mathrm{p}<.05)$, Paranoid Düşüncenin $(U=14536, p<.05)$ ve Psikotizmin $(U=15791$, $\mathrm{p}<.05)$ cinsiyete göre anlamlı bir şekilde farklılaştı̆̆ ve bütün boyutlarda kadınların puanlarının erkeklerin puanlarından daha yüksek olduğu tespit edilmiştir.

\subsection{Araştırmanın Üçüncü Sorusuna İlişkin Bulgular}

$\mathrm{Bu}$ kısımda araştırmanın üçüncü sorusu doğrultusunda ergenlerde internet bağımlılığı ile psikolojik belirtilerin anne baba tutumlarına göre anlamlı şekilde farklılaşıp farklılaşmadığını belirlemek için Kruskal Wallis $H$ testi yapılmış ve sonuçlar Tablo 4'te verilmiştir.

Tablo 4 incelendiğinde ergenlerin internet bağımlılı̆̆ düzeylerinin anne baba tutumlarına göre anlamlı bir şekilde farklılaştığı $\left(x_{(3)}^{2}=9.28, \mathrm{p}<.05\right)$ görülmektedir. Anlamlı 
farklılığın hangi tutumlarda olduğunun tespit edilmesi için Mann-Witney U testi yapılmıştır. Karşılaştırma sonucunda anlamlı farklılığın otoriter anne baba tutumu (Sıra ort= 246.36) ile demokratik anne baba tutumu (Sira ort=191.23) arasinda otoriter anne baba tutumu aleyhine $(\mathrm{U}=2891.500$ $\mathrm{p}<.05$ ); otoriter anne baba tutumu (Sira ort= 246.36) ile koruyucu anne baba tutumu (Sira ort= 210.15) arasinda otoriter anne baba tutumu aleyhine ( $U=5082.000 \mathrm{p}<.05)$ olduğu tespit edilmiştir. Bu bulgu otoriter anne babaların çocuklarının demokratik ve koruyucu anne babaların çocuklarından daha fazla internet bağımlısı olduğunu göstermektedir. Tablo 4'de ergenlerin psikolojik belirti düzeylerinin anne baba tutumlarına göre anlamlı bir şekilde farklılaştığg $\left(x_{(3)}^{2}=22,301, \mathrm{p}<.05\right)$ görülmektedir. Farklılığın kaynağını tespit etmek için yapılan Mann Witney U testi sonuçlarına göre anlamlı farklılığın demokratik anne baba tutumu (Sira ort=186.45) ile otoriter anne baba tutumu (Sira ort=237.72) arasında otoriter anne baba tutumu aleyhine $(\mathrm{U}=2993.000 \mathrm{p}<.05)$; demokratik anne baba tutumu (Sira ort=186.45 ) ile ilgisiz anne baba tutumu (Sira ort=293.55) arasinda, ilgisiz anne baba tutumu aleyhine ( $U=974.000$ $\mathrm{p}<.01)$ ve koruyucu anne baba tutumu (Sira ort=206.33) ile ilgisiz anne baba tutumu (Sira ort=293.55) arasında olduğu ilgisiz anne baba tutumu aleyhine ( $U=1743.500 \mathrm{p}<.05)$; ilgisiz anne baba tutumu (Sira ort=293.55) ile otoriter anne baba tutumu (Sira ort=237.72) arasında ilgisiz anne baba tutumu aleyhine $(\mathrm{U}=671.000 \mathrm{p}<.05)$ olduğu tespit edilmiştir. $\mathrm{Bu}$ bulgu otoriter ve ilgisiz anne babaların çocuklarının demokratik ve koruyucu anne babaların çocuklarından daha fazla psikolojik belirti gösterdiğini ifade etmektedir. Ayrıca ilgisiz anne baba tutumuna sahip ebeveynlerin çocuklarının psikolojik belirti düzeylerinin en yüksek olduğunu göstermektedir.

\subsection{Araştırmanın Dördüncü Sorusuna İlişkin Bulgular}

$\mathrm{Bu}$ kısımda araştırmanın dördüncü sorusu doğrultusunda ergenlerde internet bağımlılığı ile psikolojik belirtilerin internete bağlanma amacına göre anlamlı şekilde farklılaşıp farklılaşmadığını belirlemek için Kruskal Wallis H testi yapılmış ve sonuçlar Tablo 5 'te verilmiştir.

Tablo 5 incelendiğinde internete bağlanma amacina göre internet bağımlılığının anlamlı şekilde farklılaştığı $\left(x^{2}{ }_{(5)}=\right.$ 47.390, p<.05) görülmektedir. İnternet bağımlılı̆̆ının hangi amaca göre farklılaştığını belirlemek için Mann-Witney U testi yapılmıştır. Analiz sonuçlarına göre araştırma amacıyla internete girme (Sıra ort=130.85) ile eğlence amaçlı internete girme (Sıra ort=228.17) arasında eğlence amacı aleyhine $(\mathrm{U}=2219.500 \mathrm{p}<.01)$; araştırma amaciyla internete girme (Sira ort $=130.85$ ) ile sohbet amaciyla internete girme (Sira ort $=231.61)$ arasinda sohbet amac1 aleyhine $(\mathrm{U}=2389.000$ $\mathrm{p}<.01)$; araştırma amaciyla internete girme (Sıra ort=130.85) ile oyun amaçlı internete girme $($ Sıra ort=252.77) arasında oyun amaçlı internete girme aleyhine $(\mathrm{U}=1079.000 \mathrm{p}<.01)$ Buna göre eğlence amaçlı, sohbet amaçlı ve oyun amaçlı internete bağlananların internet bağımlılığı düzeyleri araştırma amaçlı internete bağlananlara oranla daha yüksek bulunmuştur. Tabloda psikolojik belirtilerin internete bağlanma amacına göre anlamlı şekilde farklılaşmadığı $\left(x^{2}(5)=7.248, \mathrm{p}>.05\right)$ görülmektedir.

\subsection{Araştırmanın Beşinci Sorusuna İlişskin Bulgular}

$\mathrm{Bu}$ kısımda araştırmanın beşinci sorusu doğrultusunda ergenlerde internet bağımlılığ 1 ile psikolojik belirtilerin sınıf değişkenine göre anlamlı şekilde farklılaşıp farklılaşmadığını belirlemek için Kruskal Wallis $H$ testi yapılmış ve sonuçlar Tablo 6' da verilmiştir.

Tablo 6 incelendiğinde sınıf değişkenine göre internet bağımlılığının anlamlı şekilde farklılaşmadığı $\left(x_{(3)}^{2}=2.347\right.$, p>.05 görülmektedir. Tablo 6'da psikolojik belirtilerin sınıf değişkenine göre anlamlı şekilde farklılaştığı $\left(x^{2}{ }_{(3)}=16.921\right.$, $\mathrm{p}<.05) \quad$ görülmektedir. Psikolojik belirtilerdeki farklılaşmanın hangi sınıflar arasında olduğunu tespit etmek için Mann-Witney U testi yapılmıştır. Analiz sonuçlarına göre 9. $\sin 1 f$ (Sira ort=188.24 ) ile 11. $\sin 1 f$ (Sira ort=243.08) arasında 11. sınıf aleyhine anlamlı şekilde farklılaştığ $(\mathrm{U}=5077500 \mathrm{p}<.05), 10$. sinif (Sira ort=192.98) ile 11. sinif (Sıra ort=243.08) arasında 11. sınıf aleyhine anlamlı şekilde farklılaştığı $(U=8459.500 \mathrm{p}<.05)$ görülmektedir. Bu bulguya göre sınıf düzeyi arttıkça psikolojik belirti düzeyleri de artmaktadır.

\subsection{Araştırmanın Altıncı Sorusuna İlişkin Bulgular}

$\mathrm{Bu}$ kısımda araştırmanın altıncı sorusu doğrultusunda ergenlerde internet bağımlılığı ve psikolojik belirtilerin internette kalma süresi ile ilişkisi Spearman Korelasyon Analizi ile incelenmiş ve sonuçlar Tablo 7'de verilmiştir.

Tablo 7. İnternet Bağımlılığı ve Psikolojik Belirtilerin İnternette Kalma Süresi ile İlișkisi

\begin{tabular}{lccc}
\hline Değişkenler & 1 & 2 & 3 \\
\hline Süre & 1 & & \\
İnternet Bağımlılı̆̆ & $0.443 * *$ & 1 & \\
Psikolojik Belirti & $0.199^{* *}$ & $0.372^{* *}$ & 1 \\
\hline$* * \mathrm{p}<.01$ & & &
\end{tabular}

Tablo 7 incelendiğinde internette kalma süresi ile internet bağımlılığı arasında orta düzeyde pozitif yönlü anlamlı bir ilişki $\left(r_{s}=.443, p<0.01\right)$, psikolojik belirtiler ile de $\left(r_{s}=20\right.$, $\mathrm{p}<0.01)$ düşük düzeyde pozitif yönlü anlamlı bir ilişki olduğu görülmektedir. Bu bulguya göre internette kalma süresi arttıkça internet bağımlılığı ve psikolojik belirti puanları artmaktadır.

\subsection{Araştırmanın Yedinci Sorusuna İlişkin Bulgular}

$\mathrm{Bu}$ kısımda araştırmanın yedinci sorusu doğrultusunda ergenlerde internet bağımlılığı ve psikolojik belirtilerin yaş ile ilişkisi Spearman Korelasyon Analizi ile incelenmiş ve sonuçlar Tablo 8'de verilmiştir.

Tablo 8 incelendiğinde araştırmanın bir diğer değişkeni olan yaş ile internet bağımlılığı arasında her hangi bir ilişki $\left(\mathrm{r}_{\mathrm{s}}=.082, \mathrm{p}>0.05\right)$ bulunmadığ 1 , psikolojik belirtiler ile yaş değişkeni arasında düşük düzeyde pozitif yönlü ilişki $\left(r_{s}=196, p=.000, p<0.01\right)$ olduğu görülmektedir. Bu bulguya göre yaşın artması internet bağımlılığı puanlarını artırmazken, psikolojik belirti puanlarını artırmaktadır. 
Tablo 8. İnternet Bağımlılı̆̆ı ve Psikolojik Belirtilerin Yaş Değişkeni ile İlişkisi

\begin{tabular}{lccc}
\hline Değişkenler & 1 & 2 & 3 \\
\hline Yaş & 1 & & \\
İnternet Bağımlılı̆̆ & 0.082 & 1 & \\
Psikolojik Belirti & $0.196^{* *}$ & $0.372^{* *}$ & 1 \\
\hline$* * \mathrm{p}<.01$ & & &
\end{tabular}

\section{Sonuç}

$\mathrm{Bu}$ araştırmanın amacı lisede okuyan ergenlerin internet bağımlılık düzeyleri ile psikoloji belirtileri arasındaki ilişkiyi ve bu iki kavramı yaş, cinsiyet, sınıf, anne baba tutumu, internete bağlanma amacı ve internette kalma süresi değişkenleri açısından incelemektir.

Araştırma sonucunda ergenlerin internet bağımlılık düzeyleri ve psikolojik belirti düzeyleri toplam puanları ile psikolojik belirti alt boyutları (somatizasyon, obsesif kompülsif bozukluk, kişilerarası duyarlılık, depresyon, anksiyete, fobik anksiyete, paranoid düşünce, düşmanlık ve psikotizm) arasında pozitif yönlü anlamlı ilişki olduğu tespit edilmiştir. Bu sonuç internet bağımlılı̆̆ı arttıkça psikolojik belirtilerin arttığı aynı zamanda psikolojik belirtiler arttıkça internet bağımlılığının da arttığı anlamına gelmektedir. Bu bulgu alan yazında psikolojik belirtilerle ilgili yapılan çalışmalarla (Shapira vd., 2000; Yao ve Zhong, 2014; Durak Batıgün ve Kılıç, 2011; Dalbudak ve Evren, 2014; Ko vd., 2012) ve psikolojik belirti alt boyutlarından depresyon (Gholamian, Shahnazi ve Hassanzadeh, 2017; McNicol ve Thorsteinsson, 2017; Odacı ve Çikrıkçi, 2017; Çetinkaya, 2013; Ko vd., 2014; Kim vd., 2006; Ko vd., 2009; Yen, Ko, Yen, Chen ve Chen, 2009; Young ve Rogers, 1998), anksiyete (Gholamian vd., 2017; McNicol ve Thorsteinsson, 2017; Odacı ve Çikrıkçi, 2017; Bernardi ve Pallanti, 2009; Clayton vd., 2013; Jie vd., 2014), psikotizm (Cao ve Su, 2006; Dalbudak ve Evren, 2014) obsesif kompülsif bozukluk (Shapira vd., 2000) hostilite (Ko vd., 2009; Ko vd., 2012) fobik anksiyete (Ko vd., 2009; Ko vd., 2012) ve kişilerarası duyarlılık (Dalbudak vd., 2013) ile ilgili çalışmalarla tutarlılık göstermektedir. Birey internette hoşnut olmadığ yönlerini gizleyip istediği kimlikle var olabilmektedir. Farklı kimlikler zamanla bireyin gerçek kimliği üzerinde olumsuz etkiler birakabilmektedir. Bu durum Proteus Etki olarak tanımlanmakta ve bireyin çevrimiçi dünyada seçtiği kimliğin veya avatarının etkisiyle kendini farklı biri olarak algılamaya başlaması şeklinde (Tanhan ve Alav, 2015) ortaya çıkmaktadır. Buna ek olarak internet dünyasının gizli olması, mahrem bir alan olması, sosyal baskıdan uzak bir ortam sağlaması interneti birey için çekici bir hale getirmektedir. $\mathrm{Bu}$ yönleriyle internetin özellikle gerçek hayatın sorunlarından kaçan veya sorunlarıyla yüzleşmek istemeyen ergenler için bir sığınak olabileceği düşünüldüğünde, internet bağımlılığı ile psikolojik belirtiler arasındaki ilişki daha net bir şekilde anlaşılabilecektir.

$\mathrm{Bu}$ araştırmada internet bağımlılı̆̆ının cinsiyet değişkenine göre anlamlı şekilde farklılaşmadığı görülmüştür. Bu sonuç alan yazındaki bazı çalışmalarla tutarlıdır (McNicol ve Thorsteinsson, 2017; Ertekin vd., 2016; Dalbudak ve Evren, 2014; Durak Batıün ve Hasta, 2010; Kim vd., 2006; İsraelashvili vd., 2012, Taylan ve Işık, 2015). Bazı çalışmalarda ise bu bulguların aksine (Gholamian vd., 2017; Ayas, 2012; Çetinkaya, 2013; Alaçam, 2012; Günüç, 2009; Esen, 2010; Kılınç ve Doğan, 2014; Ko vd., 2010; Tsai vd.,
2009) internet bağımlılığının cinsiyete göre farklılaștığı ve erkeklerin daha çok bağımlı olduğu tespit edilmiştir. Bu çalışmanın isteyen herkesin kolay bir şekilde internete ulaşabildiği bir örneklem üzerinde yapılması cinsiyetler arasında anlamlı bir farklılığın bulunmamasını açıklayabilir. Psikolojik belirtilerin cinsiyet değişkenine göre anlamlı şekilde farklılaştığı ve psikolojik belirti toplam puan ile psikolojik belirti alt boyutlarında kadınların erkeklere göre anlamlı düzeyde puanlarının daha yüksek olduğu tespit edilmiştir. $\mathrm{Bu}$ bulgu alan yazındaki bulgularla tutarlıdır (Birel, 2012; Coşar Ciğerci, 2006; Düzgün, 1995; Güven ve Güçray, 2009; Jie vd., 2014; Sarı, 2008; Yıldırım, 2011; Yılmaz, 2010). Bazı çalışmalarda cinsiyetler arasında anlamlı ilişki bulunmamıştır (Gholamian vd., 2017; Sürücü, 2013). Alan yazında genel olarak kadınların psikolojik belirti düzeyleri daha yüksek bulunmaktadır. Bu durum kadınların toplumsal hayattaki rolleri ve kendilerini yeterince ifade edemedikleri için içselleştirdikleri sıkıntılar nedeniyle olabilir.

Araştırmada internet bağımlılı̆̆ının anne baba tutumlarına göre anlamlı şekilde farklılaştığ tutumuna sahip ailelerin çocuklarının internet bağımlılık düzeyleri demokratik anne baba tutumuna sahip ailelerin çocuklarının internet bağımlılık düzeylerinden daha yüksek bulunmuştur. Alan yazında bu konu ile ilgili sınırlı sayıda çalışma bulunmaktadır. Bu bulgu alan yazındaki bazı çalışmalarla tutarlı iken (Taneri ve Tiryakioğlu, 2015) bazı çalışmalarda (Ayas ve Horzum, 2013a; Büyükşahin vd., 2010) ise ilgisiz anne baba tutumuna sahip ailelerin çocuklarının internet bağımlılık düzeyleri daha yüksek bulunmuştur. $\mathrm{Bu}$ sonuçtan hareketle otoriter anne baba tutumunun ergende olumsuz değerlendirilme korkusu yaratabileceği (Erkan vd., 2002) ve bu nedenle ergenlerin kendilerini ifade etmelerini engelleyebileceği söylenebilir. Otoriter anne baba tutumunun ergenlerin sosyal kaçınma davranışı göstermelerine neden olarak (Erkan vd., 2002) sosyalleşme ihtiyaçlarını karşılamalarını engelleyebileceği, bu durumun içe kapanmaya ve yalnızlaşmaya neden olabileceği düşünülebilir. Bütün bu durumların ergenleri başka arayışlara itebileceği ve ergenlerin bu ihtiyaçlarını başka bir dünya olan sanal dünyada karşılamaya çalışacağı söylenebilir. Çalışmada anne baba tutumlarının psikolojik belirtiler açısından anlamlı şekilde farklılaştığı ve otoriter ve ilgisiz anne baba tutumunun demokratik ve koruyucu anne baba tutumuna göre anlamlı şekilde daha fazla psikolojik belirtiye neden olduğu tespit edilmiştir. $\mathrm{Bu}$ bulgu alan yazındaki çalışmalarla (Benk, 2006; Düzgün, 1995; Özer, 2011) tutarlıdır. İlgisiz ve otoriter anne babaların demokratik anne babalara oranla çocuklarının temel psiko-sosyal ihtiyaçlarını bastıracakları ya da bu ihtiyaçlarla hiç ilgilenmeyebilecekleri düşünüldüğünde bu durumun psikolojik belirtilerde artışa neden olacağı söylenebilir.

Araştırmanın bir diğer değişkeni olan internete bağlanma amacına göre internet bağımlılığının anlamlı şekilde farklılaştığ1, eğlence, sohbet ve oyun amaçlı internete giren ergenlerin araştırma amaçlı internete girenlere oranla internet bağımlılığı puanları daha yüksek bulunmuştur. Bu bulgu alan yazındaki çalışmalarla (Alaçam, 2012; Durak Batıgün ve Kılıç, 2011; Tanrıverdi, 2012) tutarlıdır. Oyun, eğlence ve sohbet amaçlı internete giren ergenlerin internette daha fazla zaman geçireceği ve bu uzun sürede daha farklı çevreler edineceği dikkate alındığında bu durumun bireyi internete daha fazla bağlayacağı söylenebilir. Psikolojik 
belirtilerin internete bağlanma amacına göre anlamlı şekilde farklılaşmadığı tespit edilmiştir. Psikolojik belirtiler genel internet bağımlılığ 1 ile ilişkili olduğundan internetin özel bir amaç için kullanılması ile ilişkisi çıkmayabilir. Yani internetin hangi amaçla kullanıldığından daha çok internet bağımlılı̆̆ının genel olarak kendisi psikolojik belirtilerle ilişkili olduğundan böyle bir sonuç çıkmış olabilir.

Araştırmanın bir diğer değişkeni olan sınıf düzeyine göre internet bağımlılığının farklılaşmadığı görülmektedir. Bu bulgu literatürdeki bazı çalışmalarla (Çakır vd., 2011; Tanrıverdi, 2012) tutarlıdır. Buna karşın bazı çalışmalarda da (Gholamian vd., 2017; Ayas ve Horzum, 2013a; Doğan, 2013) internet bağımlılığının sınıf düzeyine göre farklılaştığ1 tespit edilmiştir. Her sınıf düzeyindeki lise öğrencilerinin internete rahat bir şekilde ulaşabildiği ve bu nedenle sınıflar arasında anlamlı farklılık çıkmadığı söylenebilir. Buna karşın psikolojik belirtilerin sınıf değişkenine göre anlamlı şekilde farklılaştığı görülmektedir. Analiz sonuçlarına göre 11. sınıf öğrencilerinin 9 ve 10. sınıf öğrencilerine göre anlamlı şekilde daha fazla psikolojik belirti yaşadıkları görülmektedir. $\mathrm{Bu}$ bulgu alan yazındaki bazı çalışmalarla (Birel, 2012; Çetin, 2004) tutarlıdır. Buna karşın bazı çalışmalarda (Sarı, 2008; Yıldırım, 2011) psikolojik belirtilerin sınıf düzeyine göre anlamlı şekilde farklılaşmadığı tespit edilmiştir. Bu bulgu öğrencilerin sınıf düzeyleri arttıkça yaşadıkları duygusal dalgalanmaların artması ve sınavlar nedeniyle geleceğe ilişkin kaygıların artması ile açıklanabilir.

Araştırmanın bir diğer değişkeni olan yaş ile internet bağımlılığı arasında her hangi bir ilişki bulunmamıștır. Bu bulgu alan yazındaki çalışmalarla (İsraelashvili vd., 2012) tutarlıdır. Ancak Doğan (2013) tarafından yapılan çalışmada internet bağımlılığ 1 yaş ile ilişkili bulunmuştur. İnternete ulaşılabilirliğin her yaş grubunda bir birine yakın olması internet bağımlılı̆̆ı puanlarının yaşa göre farklılaşmamasını açıklayabilir. Psikolojik belirtilerin yaş değişkenine göre anlamlı şekilde farklılaştığı ve yaş arttıkça psikolojik belirtilerinde anlamı şekilde arttığ 1 tespit edilmiştir. $\mathrm{Bu}$ bulgu alan yazındaki bulgularla (Benk, 2006) tutarlıdır. Yaş arttıkça karşılaşılan sorunlarında artması ve çeşitlenmesi yaşa bağlı olarak psikolojik belirtileri artırabilir.

Araştırmanın bir diğer değişkeni olan internette kalma süresi ile internet bağımlılığı arasında pozitif ilişki bulunmuştur. $\mathrm{Bu}$ bulgu alan yazındaki çalışmalarla (Derin ve Bilge, 2016; Alaçam, 2012; Canan, 2010; Doğan, 2013; Durak Batıgün ve Hasta, 2010; Kaya, 2011; Kuss vd., 2013; Kubey vd., 2001) tutarlıdır. İnternet bağımlılığının internette geçirilen süre ile ilişkili çıkması beklenen bir durumdur. İnternette geçen süre arttıkça bağımlılığa neden olan işlevsizliğin, günlük hayatın diğer alanlarının, işin, okulun, aile hayatının ihmal edilmesi gibi etkenlerin artması beklenir. İnternette geçirilen sürenin psikolojik belirtilerle pozitif ilişkili olduğu görülmektedir. Alan yazında ilgili bir çalışmaya rastlanmamıştır. Ancak psikolojik belirtilerle internet bağımlılığı arasındaki ilişki dikkate alındığında internette geçirilen süre ile psikolojik belirtiler arasındaki ilișki beklenen bir durumdur.

Sonuç olarak bu çalışmada internet bağımlılığı ile psikolojik belirtiler arasında olumlu bir ilişki olduğu ortaya çıkmıştır. İnternet bağımlılığının cinsiyet, sınıf ve yaş düzeylerine göre

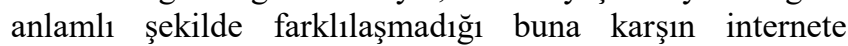
bağlanma amacı, internette kalma süresi ve anne baba tutumlarına göre anlamlı şekilde farklılaştığı tespit edilmiştir. Psikolojik belirtilerin internete bağlanma amacına göre anlamlı şekilde farklılaşmadığı buna karşın yaş, cinsiyet, internette kalma süresi, anne baba tutumları ve sınıf değişkenlerine göre anlamlı şekilde farklılaştığ edilmiştir.

$\mathrm{Bu}$ araştırmada ortaya çıkan internet bağımlılı̆̆ı ile psikolojik belirtiler arasındaki ilişki dikkate alındığında ergenlere sağlanacak psikolojik desteğin ergenlerde internet bağımlılığını azaltabileceği düşünülebilir. Ergenelere yönelik yapılacak çalışmalarda psikolojik olarak onları rahatlatacak etkinliklere yer verilmesi ve ergenlerin gelişimsel özelliklerinin dikkate alınması internet bağımlılığının gelişiminde ve ilerlemesinde önleyici bir etkiye sahip olabilir. Araştırmada anne baba tutumlarının hem internet bağımlılığı hem de psikolojik belirtilerle ilişkili olduğu tespit edilmiştir. Bu doğrultuda anne baba eğitimleri düzenlenerek veliler, anne baba tutumları ve bu tutumların yarattığı sonuçlar hakkında bilgilendirilebilir. Oyun, eğlence ve sohbet amaçlı internete girmenin internet bağımlılı̆̆ ilişkili olduğu tespit edilmiştir. Buradan hareketle ergenlere yönelik düzenlenecek sosyal ve eğlenceli aktivitelerin ergenlerin bu ihtiyaçlarını gerçek hayatta sağlamalarına imkân sağlayabilir. Bu durum aynı zamanda internette geçirilen süreyi de azaltacağından, internet bağımlılığı ve psikolojik belirtilerin internette geçirilen süre ile ilişkisi dikkate alındığında, ergenlerin internet bağımlılık düzeylerini ve psikolojik belirti düzeylerini düşürebilir. Araştırmada ayrıca sınıf düzeyi, yaş ile psikolojik belirtiler ile ilişkili olduğu tespit edilmiştir. Her iki değişkenin bir biri ile ilişkili olduğu dikkate alındığında ergenlere ergenlik dönemi ve ergenlik sonrası karşılaşabilecekleri sorunlar hakkında bilgi verilmesi bu konuda farkındalık kazanmalarının sağlanması psikolojik belirti düzeylerini azaltabilir. Psikolojik belirtiler ile internet bağımlılığ arasındaki ilişkiyi inceleyen az sayıda çalışma vardır. $\mathrm{Bu}$ çalışmalar artırılarak her iki kavram arasındaki ilişki daha da belirgin hale getirilebilir. Her iki kavram arasındaki ilişki dikkate alındığında, ergenlerin psikolojik belirtilerini azaltmaya yönelik psiko-eğitim programlarının internet bağımlılığını azaltacağı düşünülebilir.

\section{Kaynakça}

Alaçam, H. (2012). Denizli Bölgesi Üniversite Öğrencilerinde Internet Bă̆ımlılı̆̆ının Görülme Sıklı̆g ve Yetişkin Dikkat Eksikliği Hiperaktivite Bozukluğu ile Ilişkisi. Tıpta Uzmanlık Tezi. Aydın: Pamukkale Üniversitesi.

Arslan, G. (2017). Psychological maltreatment, forgiveness, mindfulness, and internet addiction among young adults: A study of mediation effect. Computer in Human Behavior, 72, 57-66. http://dx.doi.org/10.1016/j.chb.2017.02.037.

Ayas, T. (2012). The relationship between internet and computer game addiction level and shyness among highschool students. Educational Sciences: Theory \& Practise, 12(2), 632-636.

Ayas, T., \& Horzum, M.B. (2013a). İlköğretim öğrencilerinin internet bağımlılığı ve aile internet tutumu. Türk Psikolojik Danışma ve Rehberlik Dergisi, 4(39), 46-57. 
Ayas, T., \& Horzum, M.B. (2013b). Relation between depression, loneliness, self-esteem and internet addiction. Education, 133(3), 283-290.

Ayas, T., Çakır, Ö., \& Horzum, M.B. (2011). Ergenler için bilgisayar bağımlılı̆̆ı ölçeği. Kastamonu Ĕ̌itim Dergisi, 19(2), 439-448.

Benk, A. (2006). Üniversite Öğrencilerinde Mükemmeliyetçi Kişilik Özelliğinin Psikolojik Belirtilerle İlişkisi. Yüksek Lisans Tezi. İstanbul: Marmara Üniversitesi.

Beranuy, M., Oberst, U., Carbonell, X., \& Chamarro. (2009). Problematic internet and mobile phone use and clinical symptoms in college students: The role of emotional intelligence. Computers in Human Behavior, 25, 1182 1187.

Bernardi, S., \& Pallanti, S. (2009). Internet addiction: a descriptive clinical study focusing on comorbidities and dissociative symptoms. Comprehensive Psychiatry, 50, 510-516.

Birel, S. (2012). Lise Öğrencilerinin Bazı Değişkenlere Göre Rekabetçi Tutum, Psikolojik Belirtiler ve Problem Çözme Beceri Düzeyleri. Yüksek Lisans Tezi. Samsun: Samsun On dokuz Mayıs Üniversitesi.

Büyükşahin Çevik, G., \& Çelikkaleli, Ö. (2010). Ergenlerin arkadaş bağlılığı ve internet bağımlılığının cinsiyet, ebeveyn tutumu ve anne baba eğitim düzeylerine göre incelenmesi. Ç. Ü. Sosyal Bilimler Enstitüsü Dergisi, 19(3), 225-240.

Canan, F. (2010). Üniversite Öğrencilerinde Internet Bă̆ımlılı̆̆l, Disosiyatif Belirtiler ve Sosyodemografik Özellikler Arasındaki İlişki. Tıpta Uzmanlık Tezi. Düzce: Düzce Üniversitesi.

Cao, F., \& Su, L. (2006). Internet addiction among Chinese adolescents: prevalence and psychological features. Child: Care, Health and Development, 33(3), 275-281.

Chou, C., \& Hsiao, M.C. (2000). Internet addiction, usage, gratification, and pleasure experience: The Taiwan college students' case. Computers and Education, 35, 6580 .

Chou,C., Condron, L.A., \& Belland, J.C. (2005). Review of the research on internet addiction. Educational Psychology Review, 17(4), 363-388. 10.1007/s10648005-8138-1.

Clayton, R.B., Osborne, R.E., Miller, B.K., \& Oberle, C.D. (2013). Loneliness, anxiousness, and substance use as predictors of facebook use. Computers in Human Behavior, 29, 687-693.

Coşar Ciğerci Z. (2006). Üstün Yetenekli Olan ve Olmayan Ergenlerde Benlik Saygısı Başkalarının Algllaması ve Psikolojik Belirtiler Arasındaki İlişkiler. Yüksek Lisans Tezi. Sakarya. Sakarya Üniversitesi.

Cüceloğlu, D. (1994). İnsan ve davranışı. İstanbul: Remzi Kitabevi.

Çakır, Ö., Ayas, T., \& Horzum, M.B. (2011). An investigation of university students, internet and game addiction with respect to several variables. Ankara
University, Journal of Faculty of Educational Sciences, 44(2), 95-117.

Çetin, H. (2004). Yetiştirme Yurtlarındaki Adölesanların Psikolojik Belirtileri ve Benlik Saygllarl. Doktora Tezi. Ankara: Hacettepe Üniversitesi.

Çetinkaya, M. (2013). Illköğretim Öğrencilerinde Internet Bă̆ımlılı̆̆ının İncelenmesi. Yüksek Lisans Tezi. İzmir: Dokuz Eylül Üniversitesi.

Dalbudak, E., \& Evren, C. (2014). The relationship of internet addiction severity with attention deficit hyperactivity disorder symptoms in Turkish University students; impact of personality traits, depression and anxiety. Comprehensive Psychiatry, 55, 497-503. http://dx.doi.org/10.1016/j.comppsych.2013.11.018.

Dalbudak, E., Evren, C., Topçu, M., Aldemir, S., Coşkun, K.Ş., Bozkurt, M., Evren, B., \& Canbal, M. (2013). Relationship of internet addiction with impulsivity and severity of psychopathology among turkish university students. Psychiatry Research, 210, 1086-1091.

Davis, R.A. (2001). A cognitive-behavioral model of pathological internet use. Computers in Human Behavior, 17, 187-195.

Derin, S., \& Bilge, F. (2016). Ergenlerde internet bağımlılığ1 ve öznel iyi oluş düzeyi. Türk Psikolojik Danışma ve Rehberlik Dergisi, 6(46), 35-51.

Doğan, A. (2013). Internet Bă̆ımlılı̆̆l Yaygınlı̆̆ı. Yüksek Lisans Tezi. İzmir: Dokuz Eylül Üniversitesi.

Döner, C. (2011). IIlköğretim Öğrencilerinde Internet Bă̆ımlılı̆̆ının Farklı Değişkenlere Göre Incelenmesi. Yüksek Lisans Tezi. Ankara: Ankara Üniversitesi.

Durak Batıgün, A., \& Hasta, D. (2010). İnternet bağımlılığı: Yalnızlık ve kişilerarası ilişki tarzları açısından bir değerlendirme. Anadolu Psikiyatri Dergisi, 11, 213-219.

Durak Batıgün, A., \& Kılıç, N. (2011). İnternet bağımlılığı ile kişilik özellikleri, sosyal destek, psikolojik belirtiler ve bazı sosyo-demografik değişkenler arasındaki ilişkiler. Türk Psikoloji Dergisi, 26(67), 1-10.

Düzgün, Ş. (1995). Lise Öğrencilerinin Anne Baba Tutumları ile Psikolojik Belirtileri Arasındaki İlişkiler. Doktora Tezi. Erzurum: Atatürk Üniversitesi.

Erkan, Z., Güçray, S., \& Çam, S. (2002). Ergenlerin sosyal kaygı düzeylerinin ana baba tutumları ve cinsiyet açısından incelenmesi. Çukurova Üniversitesi Sosyal Bilimler Enstitüsü Dergisi, 10(10), 64-75.

Eroğlu, Y. (2016). Üniversite öğrencilerinde problemli internet kullanımı: İlişkisel-karşılıklı bağımlı benlik kurgusu ve dürtüselliğin yordama güçleri. Turkish Studies. International Periodical fort he Languages, Literature and History of Turkish or Turkıc, 11(3), 10911114. http://dx.doi.org/10.7827/TurkishStudies.9102, Ankara.

Ertekin, Y.H., Ertekin, H., Uludağ, A., \& Tekin, M. (2016). İlköğretim sekizinci sınıf öğrencilerinde internet bağımlılığı: Çanakkale örneklemi. Türk Aile Hek. Derg, 20(2), 72-76. 1015511/tahd.16.21672. 
Esen, E. (2010). Ergenlerde Internet Bă̆ımlılı̆̆ını Yordayan Psiko-Sosyal Değişkenlerin Incelenmesi. Yayınlanmamış Yüksek Lisans Tezi. İzmir: Dokuz Eylül Üniversitesi.

Gholamian, B., Shahnazi, H., \& Hassanzadeh, A. (2017). The prevalence of internet addiction and its association with depression, anxiety, and stress, among high school students. Int J Pediatr, 5(4), 4763-4770.

Griffiths, M. (2000). Does internet and computer "addiction" exist? some case study evidence. Cyberpsychology \& Behavior, 3(2), 211-218.

Griffiths, M. (2001). Sex on the internet: Observations and implications for internet sex addiction. The Journal of Sex Research. 38(4), 333-342.

Günüç, S. (2009). Internet Bă̆ımlılık Ölçeğinin Geliştirilmesi ve Bazı Demografik Değişkenler ile Internet Băğmlılı̆̆ Arasındaki İlişkilerin İncelenmesi. Yayınlanmamış Yüksek Lisans Tezi. Van: Yüzüncü Yıl Üniversitesi.

Güven, İ. G. S., \& Güçray, S. S. (2009). Ergenlerin psikolojik belirtileri ve genel sağlık örüntüleri. $M$. $\ddot{U}$. Atatürk Ĕgitim Fakültesi Ĕ̆itim Bilimleri Dergisi, 30, 119-136.

Güzel, M. (2006). Küreselleşme, internet ve gençlik kültürü. Küresel İletişim Dergisi, 1, 1-16.

İsraelashvili, M., Kim, T., \& Bukobza, G. (2012). Adolescents' over-use of the cyber world - internet addiction or identit exploration? Journal of Adolescence, $35,417-424$.

Jie, T., Yizhen, Y., Yukai, D., Ying, W., Dongying, Z., \& Jiaji, W. (2014). Prevalence of internet addiction and its association with stressful life events and psychological symptoms among adolescent internet users. Addictive Behaviors, 39, 744-747.

Johansson, A., \& Götestam, G. (2004). Internet addiction: characteristics of a questionnaire and prevalence in Norwegian youth (12-18 Years). Scandinavian Journal of Psychology, 45, 223-229.

Kalkan, M., \& Kaygusuz, C. (2013). Internet bă̆ımlılı̆̆ı. Ankara: Anı Yayıncılık.

Karaca, M. (2007). Aileyi tehdit eden yeni bir tehlike: sanal ilişkiler. e-Journal of New World Sciences Academy, 2(3), 131-143.

Karasar, N. (2004). Bilimsel araştırma yöntemi (15. Bask1). Ankara: Nobel Yayınları.

Kaya, A. (2011). Öğretmen Adaylarının Sosyal Ağ Sitelerini Kullanım Durumları Ve İnternet Bağımlılığı Düzeyleri. Yayınlanmamış Yüksek Lisans Tezi. İzmir: Ege Üniversitesi.

Kılınç, M., \& Doğan, A. (2014). Ortaokul 7. ve 8. Sinıf öğrencilerinin internet bağımlılığı ile bilişüstü farkındalıklarının çeşitli değişkenler açısından incelenmesi. Turkish Studies. International Periodical fort he Languages, Literature and History of Turkish or Turkıc, 9(5), 1385-1396.
Kim, K., Ryu, E., Chon, M. Y., Yeun, E. J., Choi, S. Y., Seo, J. S., \& Nam, B. W. (2006). Internet addiction in Korean adolescents and its relation to depression and suicidal ideation: a questionnaire survey. International journal of nursing studies, 43(2), 185-192.

Ko, C. H., Yen, J. Y., Yen, C. F., Chen, C. S., \& Chen, C. C. (2012). The association between Internet addiction and psychiatric disorder: a review of the literature. European Psychiatry, 27(1), 1-8.

Ko, C.H., Hsiao, S., Liu, G.C., Yen, J.Y., Yang, M.J. \& Yen, C.F. (2010). The Characteristics of decision making, potential to take risks, and personality of college students with internet addiction. Psychiatry Research. 175. 121125 .

Ko, C.H., Yen, J.Y., Chen, C.S., Yeh, Y.C., \& Yen, C.F. (2009). Predictive values of psychiatric symptoms for internet addiction in adolescents. Arch Pediatr Adolesc Med, 163(10), 937-943.

Kubey, R. W., Lavin, M. J., \& Barrows, J. R. (2001). Internet use and collegiate academic performance decrements: Early findings. Journal of communication, 51(2), 366382 .

Kuss, D. J., Griffiths, M. D., \& Binder, J. F. (2013). Internet addiction in students: Prevalence and risk factors. Computers in Human Behavior, 29(3), 959-966.

McNicol, M. L., \& Thorsteinsson, E. B. (2017). Internet addiction, psychological distress, and coping responses among adolescents and adults. Cyberpsychology, Behavior, and Social Networking, 20(5), 296-304.

Monacis, L., de Palo, V., Griffiths, M. D., \& Sinatra, M. (2017). Exploring individual differences in online addictions: The role of identity and attachment. International journal of mental health and addiction, 15(4), 853-868.

Odacı, H., \& Çikrıkçi, Ö. (2017). Problemli internet kullanımında depresyon, kaygı ve stres düzeyine dayalı farkl111klar. Addicta: The Turkısh Journal on Addictions, 4(1), 41-61. http://dx.doi.org/10.15805/addicta.2017.4.1.0020.

Özen, Y., Gülaçtı, F., \& Çakıll, Y. (2004). Eğitim bilimleri ve internet. Doğu Anadolu Bölgesi Araştırmaları, 52-57.

Özer, M. (2011). Suçluluk-Utanç, Bağlanma, Algllanan Ebeveynlik (Anne) Tarzl Ve Psikolojik Belirtiler Arasındaki İlişkiler. Yüksek Lisans Tezi. Ankara: Kara Harp Okulu Komutanlığg1.

Rahmani, S., \& Lavasani, M.G. (2011). The relationship between internet dependency with sensation seeking and personality. Procedia - Social and Behavioral Sciences, $30,272-277$.

Sar1, C. (2008). Ergenlerin Psikolojik Belirti Düzeyleri ve Uyumlarını Yordayan Bazı Değiskenler. Yüksek Lisans Tezi. Konya: Selçuk Üniversitesi.

Savaşır, I., \& Şahin, N.H. (1997). Bilişsel davranışçı terapilerde değerlendirme: Sık kullanılan ölçekler. Ankara: Türk Psikologlar Derneği Yayınları.

Shapira, N. A., Goldsmith, T. D., Keck, P. E., Khosla, U. M., \& McElroy, S. L. (2000). Psychiatric features of 
individuals with problematic internet use. Journal of affective disorders, 57(1), 267-272.

Shaw, M., \& Black D.W. (2008). Internet addiction. CNS Drugs, 22(5), 353-365.

Steinberg, L. (2007). Ergenlik. (Çev: Figen Çok). İstanbul: İmge Yayınları.

Sürücü, Ş. (2013). Üstün Yeteneklilerin Psikolojik Belirtileri, Stres Kaynaklarl ve Stres Karşısındaki Tepkileri. Yüksek Lisans Tezi. Tokat: Gaziosmanpaşa Üniversitesi.

Şahin Hisli, N. Batıgün Durak, A., \& Uğurtaş, S. (2002). Kısa semptom envanteri (KSE): Ergenler için kullanımının geçerlik, güvenilirlik ve faktör yapısı. Türk Psikiyatri Dergisi. 13(2), 125-135.

Taneri, P.O., \& Tiryakioğlu, Ö. (2015). Ortaokul 7. ve 8. sınıf öğrencilerinin sorunlu internet kullanımı ve anne baba tutumları ilişkisinin incelenmesi. International Journal of Social Science, 40, 205-225. http://dx.doi.org./10.9761/ASS3078

Tanhan, F., \& Alav, Ö. (2015). Siber kimliklerin kişiliğe yansıması: Proteus etki (Tanımı, Nedenleri, Önlenmesi). Online Journal of Addiction \& Cyberbullying, 2(4), 1-19.

Tanriverdi, S. (2012). Ortaöğretim Öğrencelerinde Internet Bă̆ımlılı̆̆ Illişkinin İncelenmesi. Yüksek Lisans Tezi. Van: Yüzüncü Y11 Üniversitesi.

Tao, R., Huang, X., Wang, J., Zhang, H., Zhang, Y., \& Li, M. (2010). Proposed diagnostic criteria for internet addiction. Addiction, 105(3), 556-564.

Taylan, H.H., \& Işık, M. (2015). Sakarya'da ortaokul ve lise öğrencilerinde internet bağımlılı̆̆ı. Turkish Studies. International Periodical for the Languages, Literature and History of Turkish or Turkic, 10(6), 855-874.

Tsai, H. F., Cheng, S. H., Yeh, T. L., Shih, C. C., Chen, K. C., Yang, Y. C., \& Yang, Y. K. (2009). The risk factors of Internet addiction-a survey of university freshmen. Psychiatry research, 167(3), 294-299.

Ümmet, D., \& Ekşi, F. (2016). Türkiyedeki genç yetişkinlerde internet bağımlılığı: Yalnızlık ve sanal ortam yalnızlık bağlamında bir inceleme. Addicta: The Turkish Journal on Addictions, 3(1), 29-53.

Yao, M. Z., \& Zhong, Z. J. (2014). Loneliness, social contacts and Internet addiction: A cross-lagged panel study. Computers in Human Behavior, 30, 164-170.

Yellowlees, P. M., \& Marks, S. (2007). Problematic Internet use or Internet addiction?. Computers in human behavior, 23(3), 1447-1453.

Yen, J. Y., Ko, C. H., Yen, C. F., Chen, C. S., \& Chen, C. C. (2009). The association between harmful alcohol use and Internet addiction among college students: comparison of personality. Psychiatry and clinical neurosciences, 63(2), 218-224.

Yıldırım, T., Atlı, A., \& Çitil, C. (2014). Lise öğrencilerinin psikolojik yardım aramaya gönüllülükleri ile psikolojik belirtileri arasındaki ilişki. e-International Journal of Educational Research, 5(2), 89-104.
Yıldırım, Ü. (2011). Orta Öğretim Öğrencilerinin Psikolojik Belirtilerinin Sosyal Destek Algisı ve Akademik Erteleme Açısından Incelenmesi. Yüksek Lisans Tezi. Sakarya: Sakarya Üniversitesi.

Yılmaz, E.B. (2010). Zeka Türleri ile Psikolojik Belirtiler Arasındaki Illişkiler. Yüksek Lisans Tezi. Sakarya: Sakarya Üniversitesi.

Young, K. (1997). What makes the internet addictive. (Erişim: 04.04.2014), http://www.icsao.org/fileadmin/ Divers_papiers/KYoung-internetaddiction4.pdf.

Young, K., Pistner, M., O’mara, J., \& Buchanan, J. (1999). Cyber disorders: the mental health concern for the new millennium. CyberPsychology \& Behavior, 2(5), 475479.

Young, K.,S., \& Rogers, R.C. (1998). The relationship between depression and internet addiction. CyberPsychology \&Behavior. 1(1), 25-28.

Yörükoğlu, A. (1986). Gençlik çă̆ı. Ankara: Türkiye İş Bankası Kültür Yayınları. 